\title{
Perception of public school students about animal welfare and the occurrence of the
}

\section{topic in education books}

\author{
Percepção de alunos de escola pública sobre bem-estar animal e a ocorrência do tema nos livros
}

didáticos

\author{
Percepción de los estudiantes de escuelas públicas sobre el bienestar animal y la ocurrencia del \\ tema en los libros educativos
}

Received: 12/27/2021 | Reviewed: 01/01/2022 | Accept: 01/04/2022 | Published: 01/08/2022

\author{
Heliton Aparecido Sitton \\ ORCID: https://orcid.org/0000-0002-8609-0689 \\ São Paulo State University, Brazil \\ E-mail: sitton1234@hotmail.com. \\ Matheus Janeck-Araujo \\ ORCID: https://orcid.org/0000-0002-6588-4578 \\ São Paulo State University, Brazil \\ E-mailmathjaneck@hotmail.com \\ Vinicius de Lima Lovadini \\ ORCID: https://orcid.org/0000-0001-9066-2160 \\ São Paulo State University, Brazil \\ E-mail: viniciuslovadini@hotmail.com \\ Gabriela Cortellini Ferreira Ramos \\ ORCID: https://orcid.org/0000-0002-1953-4905 \\ São Paulo State University, Brasil \\ E-mail: g.cortelliniferreira@gmail.com \\ Itamar Souza Oliveira-Junior \\ ORCID: https://orcid.org/0000-0003-0849-9734 \\ Federal University of São Paulo, Brazil \\ E-mail: ramati.sojr@gmail.com \\ Márcia Marinho \\ ORCID: https://orcid.org/0000-0003-2177-6214 \\ São Paulo State University, Brazil \\ E-mailmarcia.marinho@unesp.br
}

\begin{abstract}
In current time, it is evident the necessity of animal welfare education policies. Animal welfare is defined as the state of an individual attempting to adjust to the environment and education material can encourage dialogue inside schools. We aimed to verify the presence or absence of animal welfare related content in school books and survey the perceptions of the students about the subject, associating with the socioeconomic profile of the school district and with the overall school performance in the SARESP test. This study was performed between July and November, with seven of the twenty-two public schools in the city of Araçatuba, São Paulo, Brazil. Seven books were collected for analysis from each school, totalizing 49 books, and 430 students answered a survey with 10 questions. The statistical analysis did not show relevant difference between biological gender, age, grade and socioeconomic profile and animal welfare knowledge perception. This study concluded that in most of the analyzed books, animal welfare topics are absent, and that there is no difference between the schools' socioeconomic profile and animal welfare knowledge perception of the students.
\end{abstract}

Keywords: Animal welfare; High school; Middle school; Students.

\section{Resumo}

Atualmente, fica evidente a necessidade de políticas de educação em bem-estar animal. Bem-estar animal é definido como o estado de um indivíduo que tenta se ajustar ao meio ambiente e o material educacional pode estimular o diálogo dentro das escolas. Objetivou-se verificar a presença ou ausência de conteúdos relacionados ao bem-estar animal nos livros escolares e levantar a percepção dos alunos sobre o assunto, associando ao perfil socioeconômico do distrito escolar e ao desempenho escolar geral no teste SARESP. Este estudo foi realizado entre julho e novembro, com sete das vinte e duas escolas públicas da cidade de Araçatuba, São Paulo, Brasil. Foram coletados sete livros para análise de cada escola, totalizando 49 livros, e 430 alunos responderam a uma pesquisa com 10 questões. A análise estatística não mostrou diferença relevante entre gênero biológico, idade, série e perfil socioeconômico e percepção de conhecimento sobre bem-estar animal. Este estudo concluiu que, na maioria dos livros analisados, os 
tópicos de bem-estar animal estão ausentes e que não há diferença entre o perfil socioeconômico das escolas e a percepção dos alunos sobre o conhecimento sobre bem-estar animal.

Palavras-chave: Animal bem-estar; Ensino médio; Ensino fundamental; Alunos.

\section{Resumen}

En la actualidad, es evidente la necesidad de políticas de educación en bienestar animal. El bienestar animal se define como el estado de un individuo que intenta adaptarse al medio ambiente y el material educativo puede fomentar el diálogo dentro de las escuelas. Nuestro objetivo fue verificar la presencia o ausencia de contenido relacionado con el bienestar animal en los libros escolares y sondear las percepciones de los estudiantes sobre el tema, asociándolo con el perfil socioeconómico del distrito escolar y con el desempeño escolar general en la prueba SARESP. Este estudio se realizó entre julio y noviembre, con siete de las veintidós escuelas públicas de la ciudad de Araçatuba, São Paulo, Brasil. Se recolectaron siete libros para análisis de cada escuela, totalizando 49 libros, y 430 estudiantes respondieron una encuesta con 10 preguntas. El análisis estadístico no mostró diferencias relevantes entre el sexo biológico, la edad, el grado y el perfil socioeconómico y la percepción del conocimiento del bienestar animal. Este estudio concluyó que en la mayoría de los libros analizados, los temas de bienestar animal están ausentes y que no existe diferencia entre el perfil socioeconómico de las escuelas y la percepción de conocimiento de bienestar animal de los estudiantes.

Palabras clave: Bienestar animal; Escuela secundaria; Escuela intermedia; Estudiantes.

\section{Introduction}

The teaching-learning process allows an opportunity for the evolution of educators' skills, which privileges the essence of the educational process - learning (Estrela, 2018). In this context, the introduction of new concepts to textbooks is of fundamental importance to the transformation of a society reaching all students regardless of their purchasing power.

Nowadays, it is evident the need for animal welfare education policies. Animal welfare is defined as the state of an individual attempting to adjust to the environment, in this affirmation, the state or life quality can vary between good or bad. An animal may not be able, despite several attempts, to adjust in a new environment, having therefore a poor welfare (Ludtke, 2012). The science of animal welfare has been resting on the scientific scene and establishing itself in all farming systems -livestock, pets, work, fish, and wild animals in the wild and in captivity. Causing a complex and revolutionary reflection on the way we raise and treat animals (Ramos et al., 2021)

Animal welfare policy constitutes a challenge to overcome, and schools could facilitate by encouraging dialogue among the student body. Brazilian Federal Government created in 1985 the National Didactic Book Program, through the Brazilian Education Ministry, to provide access to science and education in Brazilian public schools (Vasconcelos, 2003). Besides, another substantial fact about the didact books is the role of the school in the everyday life of the students, where the school as a whole is inside the educational system connect with a particular socio-cultural-economic environment of the population (Medina, 2001). Moreover, in most Brazilian public schools, the didactic book is the only research material available for students and teachers (Batista, 2010).

The proportion of houses with cats and dogs in Brazil were verified in the National Health Research, also employed for decision making of the Brazilian Health Ministry, such as the estimating the purchase of rabies vaccine. In 2013, it was stated that $44,3 \%$ of the Brazilian houses had at least one dog, totalizing the equivalent of 28,9 million dogs (Brazilian Institute of Geography and Statistics, 2015). The close relation between men and dogs can be justified by the urban man necessity of imitate the natural environment that he was inserted thousands of years ago. As animal domestication took place, this relationship became more affectionate and animals became a part of human life (Del-Claro, 2003).

The present study aimed to verify the presence or absence of animal welfare related content in school books and survey the perceptions of the students about the subject, associating the socioeconomic profile of the district of the school with the and animal welfare knowledge perception of the students of this schools in the SARESP test. 


\section{Methodology}

\section{Study Design}

This study was performed between July and November, with seven of the twenty-two public schools of Araçatuba city, under the administration of State Board of Education of São Paulo state. These seven schools were

intentionally selected based on their results in the São Paulo State School Performance Assessment System (SARESP). The Brazilian school grades are composed of elementary school grades (1st to 5th), middle school grades (6th to 9th) and high school grades (1st to 3rd), and the SARESP test demonstrates the performance of 9th grade of middle school and 1st grade of high school students through an external test of Portuguese language and math (Department of Education of the State of São Paulo, 2017).

Another selection criterion was the distance of the school from the downtown area, and for this we used the Google Earth software tool of district limitation.

\section{Data Collection and Analysis}

Among the selected schools, five were located at districts with poor socioeconomic profile and their SARESP performance was below the average of schools from the downtown district. According to Google Earth district limitation, two public schools selected were in the downtown district, close to the Municipal Library, Municipal Theater, sport venues and cultural presentations (Table 1).

Table 1 - Public schools' classification according to socioeconomic profile.

\begin{tabular}{lc} 
Schools name & Socioeconomic profile \\
\hline E.E. Abranche José & Low \\
E.E.C.H. Ezequiel Barbosa & Low \\
E.E. Prof José Arantes Terra & Low \\
E.E. Luiz Gama & High \\
E.E. Manoel Bento da Cruz & High \\
E.E. Prof Maria do Carmo Lélis & Low \\
E.E. Silvestre Augusto do Nacimento & Low \\
\hline
\end{tabular}

Source: Authors.

\section{Ethics approval}

This project followed the Ethics Criteria in Research with Humans according to $n^{\circ} 466 / 12$ resolution of the National Health Council and it was approved by the Human Research Ethics Committee of the Paulista State University of the Faculty of Veterinary Medicine of Araçatuba campus - UNESP under protocol n 2,305,241-2017. Araçatuba city take a place of importance in the history of cattle creation in the state of São Paulo, receiving the title of "Capital of Fat Ox" in the 60's and continues until nowadays with one of the largest agricultural and livestock exhibitions in Brazil (Fiorin, 2013). Figure 1 shows the geographic localization of each public school of this study. 
Figure 1 - Public schools' geographic localization - Araçatuba city, São Paulo state, Brazil (2018).

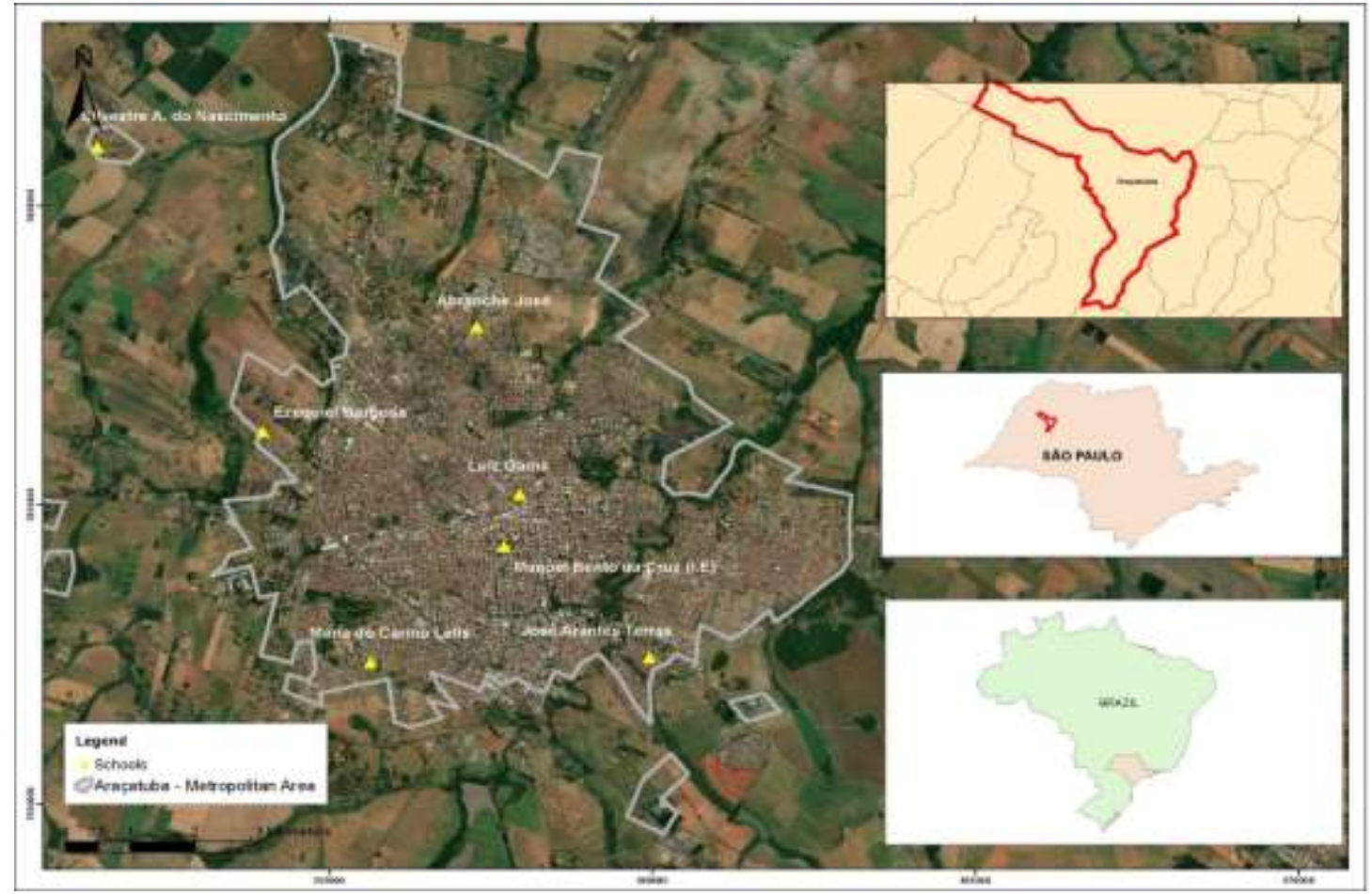

Source: Authors.

Seven didactic books were collected for analysis from each visited school, Science $(n=4)$ from $6^{\text {th }}, 7^{\text {th }}, 8^{\text {th }}$ and $9^{\text {th }}$ grades of middle school - cycle II and Biology $(n=3)$ from $1^{\text {st }}, 2^{\text {nd }}$ and $3^{\text {rd }}$ grades of high school, totalizing 49 books. The bibliographic information was analyzed (Supplementary Information 1) and content analysis was performed to check for presence or absence of animal welfare related content. The content of each book was evaluated descriptively according to Bardin (2011).

A qualitative study was carried out using a questionnaire as a data collection technique (Pereira, et al, 2018), and sstudents of the selected schools answered a survey with 10 dichotomous questions (Supplementary Information 2) adapted from Małecki and coworkers (2016), Maria (2006) and Barros and coworkers (2014). Questions were set in two categories: A questions 1 and 8 estimated the number of students; B - questions 2, 3, 4, 5, 6, 7, 8 and 10 qualified the level of perception according to the number of correct answers, following the index: $\leq 40 \%$ - below basic knowledge; $\geq 50 \%$ or $\leq 70 \%$ - basic knowledge; $\geq 80 \%$ - above basic knowledge. The score index was adapted from the SARESP test (Secretaria da Educação do Estado de São Paulo 2017).

The purpose of the survey was to verify the knowledge of the students about animal welfare and to compare the data with the socioeconomic profile of the selected district and the overall score of SARESP test of each school.

Number of students was estimated according Dhand \& Khatkar (2014). Based on the total number of students from the 22 schools of Araçatuba (13,387 students), considering 95\% of confidence level and margin of error of 5\%, a minimum sample size of 374 students was obtained. Considering the probability of some students erase the survey, the sample size was increased $15 \%$ of the minimum sample, to 430 students from the seven selected schools. Classrooms and students were randomly selected for the survey, using the BioEstat 5.3 program. It was not possible to record data blind because our study involved students' surveys data. 


\section{Statistical Analysis}

Non-parametric Chi-square test was performed using the GraphPad Prism $6^{\circledR}$ (2012) software to analyze the association between the survey score index and the socioeconomic profiles of the districts of the schools. Further, we used the spatial and point density analysis, which allows for the identification of vulnerable areas based on a kernel intensity estimator (Davies, 2010; Oliveira, 2015). We used the Incremental Spatial Autocorrelation from the ArcGIS 10.5 software, that calculates with the Moran index (I) the increasing distances and cluster intensity for each distance determined by the z-score (Câmara et al.,2004).

\section{Results}

Data from 430 students from 7 public schools of Araçatuba was obtained, 12 surveys were excluded. The results of the 418 surveys were utilized, were 54,8\% (236) of the students were females, with ages varying between 11 and 19 years old, and $45,9 \%$ (119) were male, with age between 10 and 19 years old. Students were distributed as follows: $24,6 \%(119)$ from $6^{\text {th }}$ grade, $7,9 \%$ (34) from $7^{\text {th }}$ grade, $6,2 \%$ (27) from $8^{\text {th }}$ grade and $19,5 \%$ (84) from $9^{\text {th }}$ grade, totalizing $61,4 \%$ (264) from middle school - cycle II. Further, there were 11,4 (49) students from $1^{\text {st }}$ grade, $9,3 \%(40)$ from $2^{\text {nd }}$ grade and $17,9 \%(77)$ from $3^{\text {rd }}$ grade, totalizing $38,6 \%$ (166) from high school.

The didactic books analysis showed that only one book of the 7th grade had an animal welfare related content, in the page 163, Unit 6: Invertebrate Animals, with the title "Ethics and experimentation in animals", after the Nematodes text. The others 48 didact books did not have animal welfare related content.

Statistical analysis did not reveal any significant difference between gender, age, grade and socioeconomic profile and animal welfare knowledge perception.

The results of the survey "Animal welfare knowledge perceptions", in the questions 1 to 9 did not showed statistical significance. However, in the question 10, the E.E Silvestre Augusto do Nascimento school showed statistical significance when compared with both downtown districts schools E.E. Luiz Gama and E.E Manoel Bento da Cruz.

Figure 2, it is observed in the Kernel density map that, according to the question referring to whether the participants have ever heard about animal welfare, the schools with the highest density clusters were Silvestre A. Do Nascimento, followed by Manoel Benedict of the Cross; and those with the lowest levels of knowledge on the subject were Luiz Gama and Maria do Carmo Lelis, respectively 
Figure 2 - Comparison between the frequencies obtained in the responses, according to socioeconomic profile of schools in the Question: 2 - Have you ever heard about animal welfare?

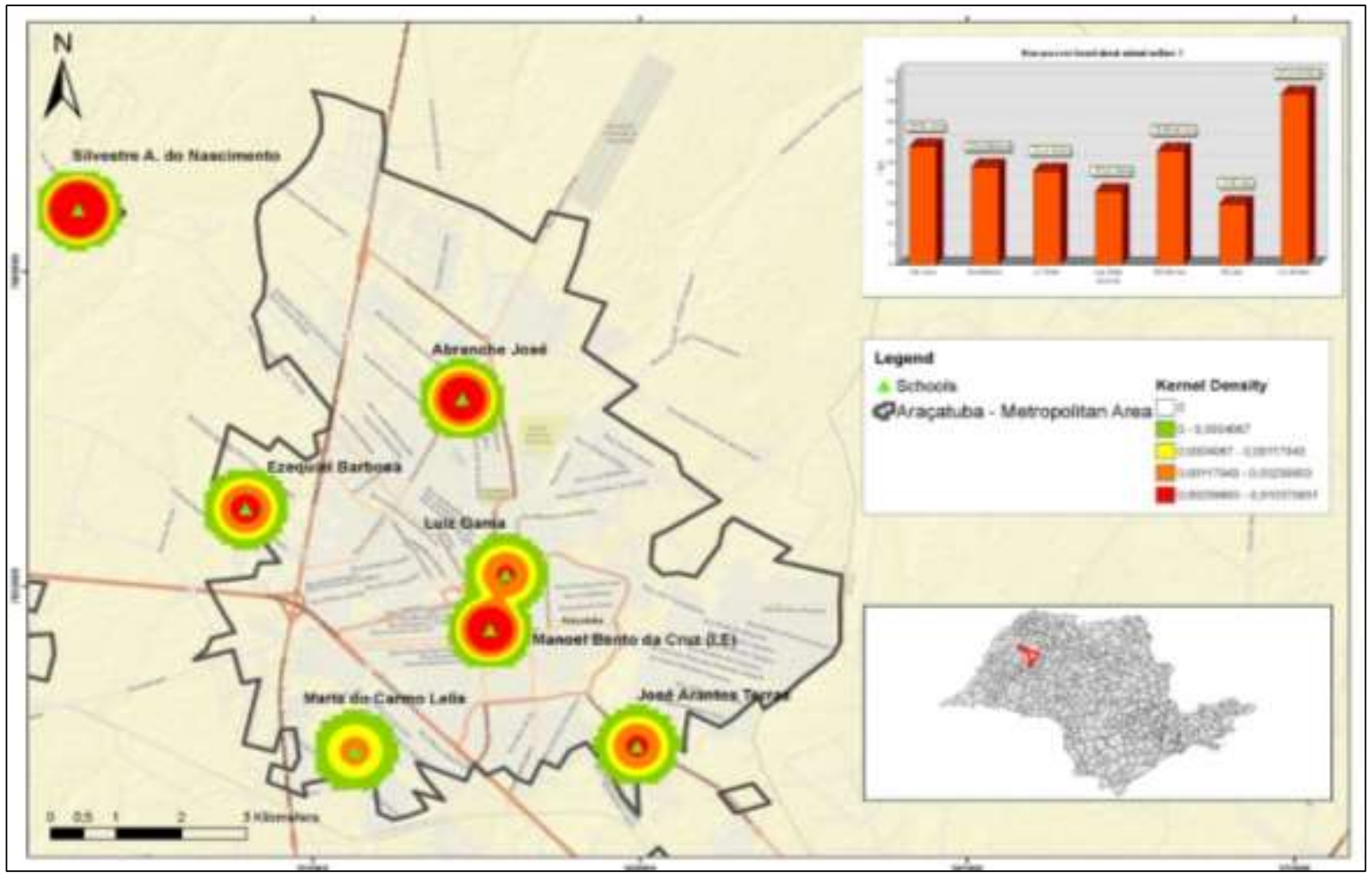

Source: Authors.

According to Figure 3, it can be seen in the Kernel density map that, according to question number five, regarding whether the participants believe that the animals are aware, the schools with the clusters with the highest densities were Silvestre A. do Nascimento followed by Abranche José; and Maria do Carmo Lelis had the lowest level of knowledge about the issue addressed. 
Figure 3 - Comparison between the frequencies obtained in the responses, according to socioeconomic profile of schools in the Question: 5 - Do you think that animals are conscious?

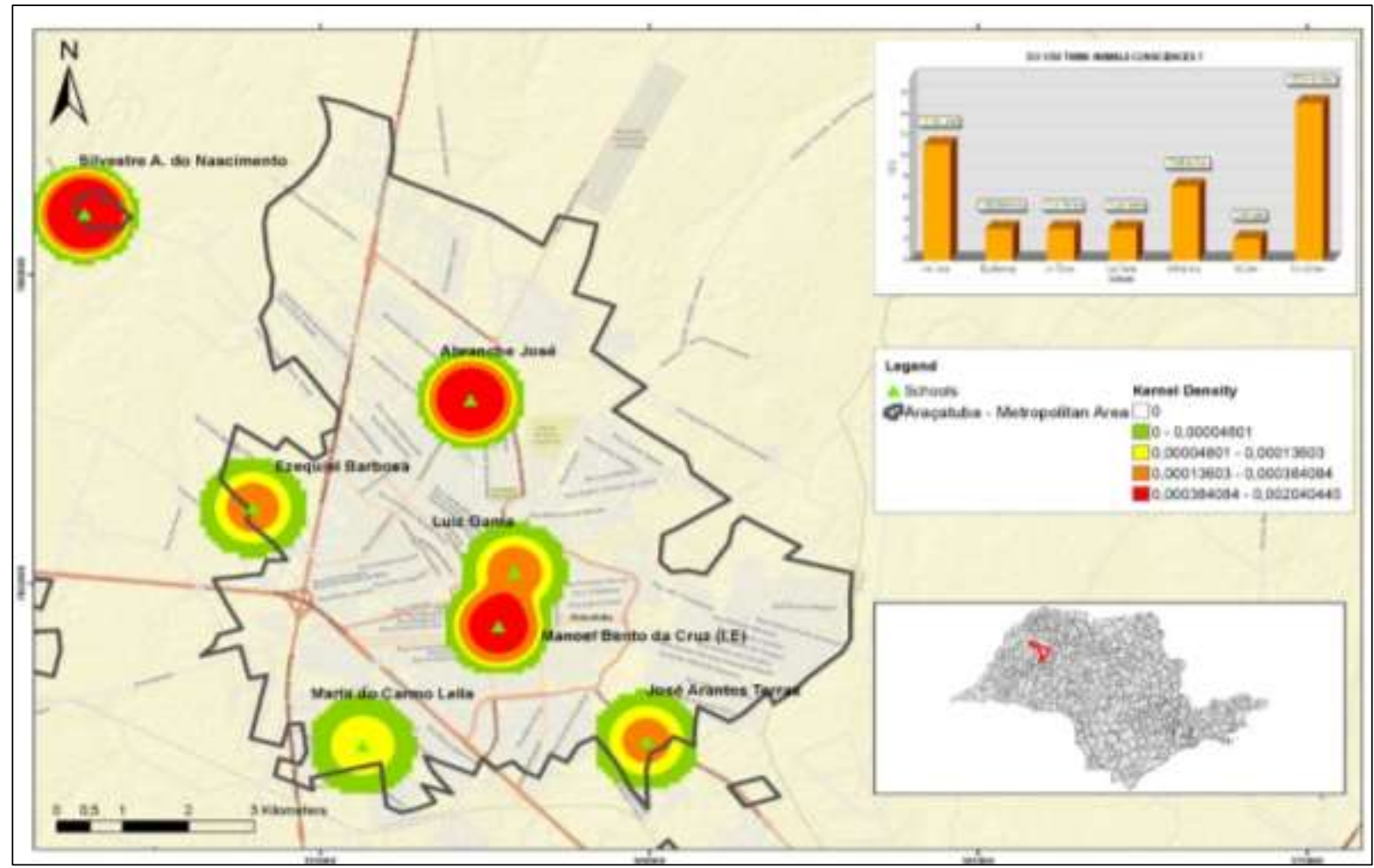

Source: Authors.

As shown in Figure 4, in the Kernel density map, with regard to question number nine, whether the participants are aware of the punitive laws for those who abuse animals, the schools with the highest density clusters were Silvestre A. do Nascimento followed by Manoel Bento da Cruz; and Maria do Carmo Lelis had the lowest level of knowledge about the issue addressed. 
Figure 4 - Comparison between the frequencies obtained in the responses, according to socioeconomic profile of schools in the Question: 9 - Are you aware that there are laws to punish who mistreat animals.

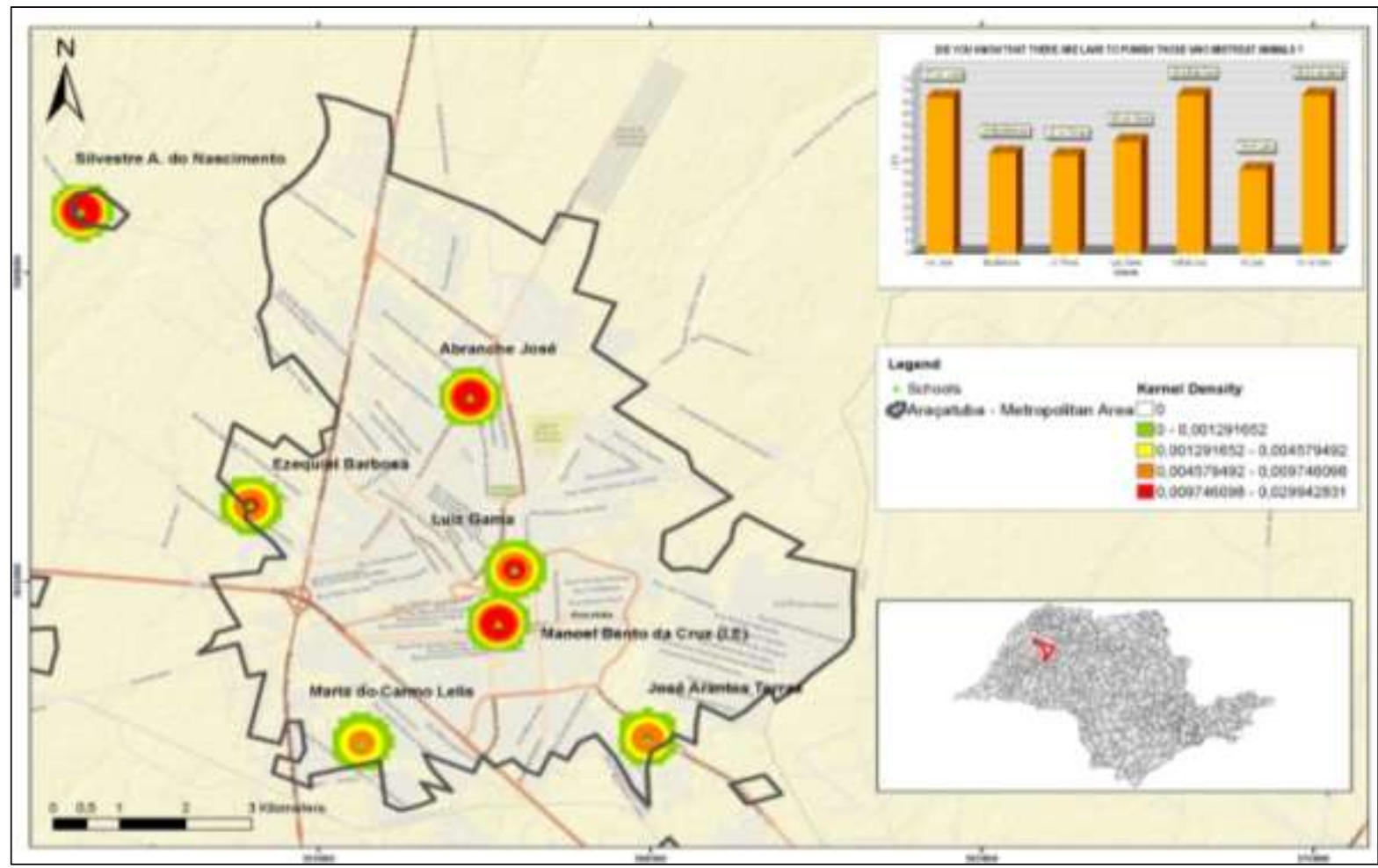

Source: Authors.

\section{Discussion}

Absence of animal welfare topics in didact books is not a modern problem, Neiman (1995) had already suggested the need of this content in Science and Biology since the elementary school grades. Topics like pet care and zoonosis are important in the beginning of elementary school grades, and a lot of teachers need external guidance to supply the lack of content of the books (Pfuetzenreiter et al., 2011). Despite the studies about the content of didact books content, there are few Brazilian publications about animal welfare topics, also, the insertion of this content in didact books to Brazilian public schools needs discussion in the Federal government sphere in which way this content will be utilized for different social realities (Farias, 2012). Also, the Brazilian guide for elementary school quality, called National Curriculum Parameters for Natural Sciences (PNCs), does not consider the inclusion of animal welfare as a minimal content to be addressed in the didact books public notices, which, in turn, affects inclusion of the topic, given that publishers tend to cover what is determined by the PNCs (Secretariat of Fundamental Education 1997; National Textbook Program 2018; Neto, 2013). Notwithstanding, publishers and authors have the autonomy to suggest relevant topics for inclusion in the PNCs contents, as it establishes the Law guidelines and base of national education (Ministry of Education, 1996). A similar study of relevant topic analysis imply that some other topics of social relevance are also lacking in didact books (Ferreira, 2008). Further, some authors suggest that actions should be taken by universities, as academic extension, to assist and raise awareness within the communities (Paixão, 2001; Silva et al. 2007).

Despite the absence of the animal welfare topic in the school books, most of the students had already heard about it. Also, most of them recognized that the animals are sentient beings and that there are laws against animal mistreatment, these results converge with those of Janine and coworkers (2016) conducted with children in the United Kingdom.

Responses provided by the students suggest that their socioeconomic profile did not influence in the animal welfare knowledge perception between the analyzed schools. However, the need for continuous access to information related to animal 
welfare is emphasized, given the circumstances show the disharmonious relationship between humans and non-human animals. Also, age, gender (biological) and grade did not significantly influence animal welfare knowledge perception. Different results were reported by Moraes and coworkers (2013), with grade affecting the knowledge about zoonosis and responsible custody of pets.

Absence of animal welfare topics in $98 \%$ of the analyzed didact books probably levels down the knowledge of the students. It is important to point that well informed students and teachers can act in a relevant way about zoonosis and animal welfare in their community (Uchoa et al., 2004).

The advance of the animal welfare topic among public-school students in is very important, because the interesting for welfare is approached the natural form since very nice. This program can offer semi-presential training to teachers from public schools about animal welfare concepts. Similarly, Moraes and coworkers (2013) showed that teacher knew better how to apply activities to the students after a formation class about zoonosis and responsible custody of pets, positively adding the animal welfare topics to the community.

Nevertheless, not only university programs can guarantee the knowledge perception of the students, this study shows that, it is important that teachers are heard before the acquisition of the didact books and their choice must reflect the real context of the students' life (Ramalho et al., 2000; Libânio, 1994).

Education is the key to change perceptions and behaviors. In this study we analyzed didactic books and students' knowledge about animal welfare from different schools of Araçatuba, a countryside city well-known by livestock farming and exhibitions in São Paulo state, Brazil. Our results showed a gap in the didactic books about this topic, which only one of the seven analyzed books had a short content about ethics and experimentation in animals. The applied survey showed that the most students from middle and high school did not know about the basics of animal welfare, regardless of the school socioeconomic profile. This knowledge is crucial for the children's perception of the welfare of their pets, zoonotic diseases and the handling of other animals.

\section{Conclusion}

This study concluded that most of the analyzed books do not contain the subject of animal welfare, and that there is no difference between the schools' socioeconomic profile and animal welfare knowledge perception by the students. In this context, other works must be carried out with the same objective.

\section{References}

Bardin L. (2011). Análise de conteúdo. Edições 70.

Barros A, Moreira L, Santos H, Ribeiro N, Carvalho L, \& Santos-Silva, F. (2014) Cancer - educate to prevent - high-school teachers, the new promoters of cancer prevention education campaigns. PLOS ONE 9(5):e96672. https://doi.org/10.1371/journal.pone.0096672

Batista M. V., Cunha M. M., \& Luna C. A. (2010), Análise do tema virologia em livros didáticos de biologia do ensino médio. Ensino Pesquisa Educação Ciências 12. http://dx.doi.org/10.1590/1983-21172010120109

Brasil, Ministério da Educação (1996). Lei de Diretrizes e Bases da Educação Nacional - Lei no 9.394/96, de 20 de dezembro de 1996. Ministério da Educação, Brasília

Brasil. Secretaria de Educação Fundamental. Parâmetros curriculares nacionais: Ciências Naturais / Secretaria de Educação Fundamental. Brasília: MEC / SEF, 1998. 138 p.

Davies, T. M. \& Hazelton, M. L. (2010). Adaptive kernel estimation of spatial relative risk. Statistic Medicine 29(23). https://doi.org/10.1002/sim.3995

Del-Claro, K. \& Prezoto, F. (2003). As distintas faces do comportamento animal. Sociedade Brasileira de Etologia e Livraria Conceito, Jundiaí

Dhand, N. K. \& Khatkar, M. S. (2014). Statulator: an online statistical calculator - Sample size calculator for estimating a single proportion. 
Druck, S., Carvalho, M. S., Câmara, G. \& Monteiro, A. V. M. (eds) "Análise Espacial de Dados Geográficos". Brasília, EMBRAPA, 2004 (ISBN: 85-7383260-6).

Estrela, C. (2018). Metodologia Cinetífica: Ciência, Ensino,Pesquisa. Editora Artes Médicas.

Farias, C. G. (2012). Comportamento animal no ensino de biologia: possibilidades e alternativas a partir de análise de livros didáticos de ensino médio. Revista Electrónica de Enseñanza de las Ciencias 11(2):365-384.

Ferreira, A. M., \& Soares C. A. (2008). Aracnídeos Peçonhentos: Análise das Informações nos Livros Didáticos de Ciências Ciência Educação 14(2):307-314. https://doi.org/10.1590/S1516-73132008000200009.

Fiorin, E. (2013). Territory of Traces: A Path by Urban Changes in Araçatuba-Sp. Cad Prudentino Geogr 35:26-38

Graphpad (2012). Prism version 6.01 for Windows. GraphPad Software, California

Instituto Brasileiro de Geografia e Estatística (2015) Pesquisa nacional de saúde: acesso e utilização dos serviços de saúde, acidentes e violências: Brasil, grandes regiões e unidades da federação. IBGE.

Janine, C., Muldoon, J. M. \& Lawrence, W. A. (2016). Exploring children's perspectives on the welfare needs of pet animals. Anthrozoös 29(3):357-375. https://doi.org/10.1080/08927936.2016.1181359

Libânio, J. C. (1994). Didática. Cortez, Editora, 05009-000.

Ludtke C. B., Ciocca, J. R. P., Barbalho, P. C., Dandin, T. V. V., Andrade J. \& Ferrarini, C. (2012). CDU 637.512:636.2 Abate humanitário de bovinos. WSPA, 148

Małecki W., Pawłowski B. \& Sorokowski P. (2016) Literary Fiction Influences Attitudes Toward Animal Welfare. PLOS ONE 12:e0168695. https://doi.org/10.1371/journal.pone.0172328.

Maria G. A. (2006). Public perception of farm animal welfare in Spain. Livestock Science 103(3):250-256. https://doi.org/10.1016/j.livsci.2006.05.011.

Medina, N. M. (2001). A formação dos professores em educação ambiental. In: Secretaria de Educação Fundamental (s.ed) Panorama da educação ambiental no ensino fundamental educação ambiental no ensino fundamental. MEC:SEF, Brasília.

Moraes, F. C. (2013). Educação em Saúde: Formação de multiplicadores em zoonoses e guarda responsável de animais de estimação. Dissertation, Universidade Estadual Paulista "Júlio de Mesquita Filho".

Neiman, Z. (1995). A importância da inserção da etologia no currículo do $2^{\circ}$ grau. In: $13^{\circ}$ Encontro Anual de Etologia. Sociedade Brasileira de Etologia, Pirassununga.

Neto J. M. \& Fracalanza, H. (2003). O livro didático de ciências: problemas e soluções. Ciência educação 9(2):147-157

Oliveira, U., Brescovit, A. D. \& Santos, A. J. (2015). Delimiting Areas of Endemism through Kernel Interpolation. PLOS ONE 10(1): e0116673. https://doi.org/10.1371/journal.pone.0116673.

Paixão, R. L. (2001). Bioética e bem-estar animal: um encontro necessário. Revista Conselho Federal de Medicina Veterinária 7(23):2-26.

Pereira, A.,S. (2018) Metodologia da pesquisa cientifica. UFSM.

Pfuetzenreiter, M. R., Mengarda D. L., Silva-Júnior, D. V., Savaris, T. \& Besen, K. P. (2011). Pesquisa-ação com professores e estudantes do ensino fundamental a partir da educação em direito animal e controle de zoonoses. In: Atas do VIII ENPEC. ABRAPEC, Campinas.

Programa Nacional Do Livro Didático (2018). Edital de convocação para o processo de inscrição e avaliação de obras didáticas para o programa nacional do livro didático PNLD 2018.

Ramalho, B. L., Núñez, I. B. \& Gauthier, C. (2000). Quando o desafio é mobilizar o pensamento pedagógico do professor: uma experiência centrada na formação continuada.

Ramos G. C. F., Garcia, SD., Araújo, M. J. \& Marinho, M. Influência do enriquecimento ambiental na reabilitação do periquitão maracanã (Psittacara leucophthalmus). Pesquisa, Sociedade e Desenvolvimento, 10, n. 17, e74101724284, 10.33448 / rsd-v10i17.24284.

Secretaria da Educação do Estado de São Paulo (2017). Saresp 2017: Sistema de Avaliação de Rendimento Escolar do Estado de São Paulo.

Silva, E. R., Pontes, C. A. \& Holanda, M. C. (2007). Bem-Estar Animal e filosofia da ciência e ética: relação de interdisciplinaridade no curso de medicina veterinária. In: Congresso Internacional de Conceitos em Bem-Estar Animal (2nd edn) UFRGS, Rio De Janeiro.

Uchoa, C. M. A., Serra, C. M. B., Magalhães, C. de M., Silva, R. M., Figliuolo, L. P., Leal, C.A. \& Madeira, M.F. (2004). Educação em saúde: ensinando a leishmaniose tegumentar americana. Cadernos de Saúde Pública 20(4):935-941.https://doi.org/10.1590/S0102-311X2004000400007.

Vasconcelos, S. D. \& Souto, E. (2003). O livro didático de ciências no ensino fundamental: proposta de critérios para análise do conteúdo zoológico. Ciência educação 9(1):93-104. 